\section{Aviation medicine capacity on facing biological threat In Indonesia airports}

\section{Yuli Subiakto \\ Pharmaceutical Institution Indonesia Air Force, Health Services Indonesia Air Force}

\begin{abstract}
Airports need high security procedures, especially for preventing outbreaks of infectious diseases spread by passenger and carried goods. Outbreaks of disease form real threat to national defense that can endanger national sovereignty, territorial integrity and national security. Biological agents that are dangerous sources of outbreaks infectious diseases can be spread by criminal and terrorists for biological warfare. Based on data, the spread of diseases in Indonesia came from abroad, such as SARS from China, Mers-CoV from the Middle East, Avian Influenza from China, HIV from Africa etc. Indonesia has a population of more than 262 million peoples, 17,500 islands, and climate conditions that allow microorganisms to grow well. In 2017 domestic flights transported $95,401,545$ persons and international flights $16,253,259$ persons, we need to prevent the spread of diseases in Indonesia entering through the Airports. Efforts to prevent the entry of dangerous biological agents in Indonesia were carried out by Quarantine Officers and Port Health Officers. The development of threat outbreak disease in air transportation is real in the future, so all Indonesia airports must have action plans to prevent the spread of infectious diseases. The Air Force must act as guardian of sovereignty by having medical personnel on the spot for role interoperability with the personnel Port Health Office for prevent the entry of dangerous biological agents. Capacity building need for be enhanced for prevention, detection, identification and response through a training of the personnel, procurement facilities for readiness prevent, detect and respond when facing biological threat.
\end{abstract}

\section{Introduction}

The threat of an infectious disease outbreak is real threat to Indonesia's national defense, because this is considered to endanger national sovereignty, territorial integrity and national security. ${ }^{1}$ The inci- dence of diseases outbreaks will increase with conditions of malnutrition, poor sanitation, poor health services, especially during natural and non-natural disasters. Conditions that support disease outbreaks make Indonesia vulnerable to outbreaks in certain areas, because there are still groups of people who are experiencing malnutrition, low sanitation behavior, and health services that have not been fully covered. In this regard, a comprehensive step is needed to prevent the entry and spread of potential biological agents, and need for steps to prevent, detect and identify, respond, handle the victims and overcome the infectious diseases among humans. ${ }^{2}$ As is known, Indonesia is hit by all kind of disasters starting from earthquakes, tsunamis, floods, landslides, eruptions, technology failure etc. ${ }^{3}$ Where such disasters often cause public health problems in form of infectious diseases, especially if the victim does not get good health services, sanitation is not repaired, or environmental damage is not immediately repaired. Spread of infectious disease is also helped by Indonesia's climate conditions that allow microbes grow and develop easily, so that infectious diseases can spread quickly, with impacts ranging from mild, moderate and severe.

In the current global era, air transportation is choice for people for moving fast or transport goods from one place to another quickly, and between regions and countries there are no limits. In addition to providing benefits community, these conditions also have an impact on spread of infectious diseases with both passenger and goods. Airports, as a place where people gather, can act as center of spread of disease and can be used as a target of terrorism by using biological agents. So that if not comprehensively anticipated it will pose a threat that if not handled well will lead to consequences that can be detrimental in terms of economy, politics and defense and state security.

\section{Biological Threat Condition in Airport}

Deliberate and accidental biological threat is using of biological weapons presents a significant challenge to our national security, our population, our agriculture, and the environment. ${ }^{2}$ Airport is strategic place and potential target for biological threat, because is place where population will meet and travel. That are areas on land and/or flying with certain limits that are used as a place for aircraft landing and taking off, boarding passengers, loading and unloading goods, and intra-and inter-mode transportation, which are equipped with flight safety, security facilities, basic facilities and other supporting facilities. ${ }^{4}$ In this
Correspondence: Yuli Subiakto, Apt. MSi, Pharmaceutical Institution Indonesia Air Force, Health Services Indonesia Air Force, Jl. Abd. Saleh, HuseinSastranegara Air Force, Base Bandung 40174, Indonesia.

E-mail: y.subiakto09@gmail.com

Key words: Biological threat in airport, aviation medicine, enhance capacity.

Conflict of interest: The author declares no conflicts of interest.

Funding: Self funding.

Acknowledgements: The author is thankful to Pharmaceutical Institutions Indonesia Air Force and Health Services Indonesia Air Forces for providing all the type of facilities to conduct write this article

Conference presentation: International Conference on Infectious Disease, Bio-Threat, and Military Medicine (INSBIOMM) 2019.

Received for publication: 17 February 2020 . Accepted for publication: 1 July 2020.

This work is licensed under a Creative Commons Attribution-NonCommercial 4.0 International License (CC BY-NC 4.0).

(C) Copyright: the Author(s), 2020

Licensee PAGEPress, Italy

Infectious Disease Reports 2020; 12(s1):8738 doi:10.4081/idr.2020.8738

regard, it can be stated that airports are a gathering point for people and goods that are vulnerable to spread of diseases which can reduce public health risks. Indonesia has a population of around $261,890,872$ persons, it spreads over 17,500 islands, and has climatic conditions that make microorganisms grow well. ${ }^{5,6}$ Seeing these conditions in context of moving people and goods more quickly make aircraft needed from city to another city, besides as a country of muslims, umrah and pilgrimage activities continue.

Airport is strategic installation, where both domestic and international passengers gather, goods, aircraft, ground crew, air crew and other flight equipment that require high security both physical and non-physical. The aviation industry was among the first major industries to define organizational safety, and to embrace risk management systems as an essential component to reduce the frequency and impact of aviation accidents. $^{7}$

As showed in Table 1, movement of people through airports domestic flight departure in Indonesia in last five years 
(2013-2017) increased by $5.38 \%$ per year, loading cargo grew by $3.51 \%$ on average per year, and loading baggage grew $4.33 \%{ }^{7}$

As showed in Table 2, passenger from international flight on average had grown by $5.47 \%$ per year, followed by growth of unloading cargo and baggage of $4.06 \%$ and $4.85 \%$. $^{7}$ In 2015 Indonesia established a Port Health Office that had inspected 1.050.818 passenger aircraft, 110.223.081 persons, of which 156.136 pilgrims, and 1500 umrah persons per day. ${ }^{8}$

The increase in the number of flights carrying humans and goods both domestically and internationally, in addition to providing benefits to the Indonesian economy also has the potential for disease transfer, whether carried by passengers or with goods, through cargo or baggage. The number of infection transmissions that occurred across the entire aircraft cabin was strikingly large. Infectious diseases and pandemics are primarily spread through aviation as a mode of travel. ${ }^{9}$ So we need to take action before creating impacts that can threaten human health in Indonesia as a result of the spread of diseases that are not controlled: it is necessary to prevent the spread of diseases through air transportation.

Base on decree MoHRoI No. 356/Menkes/Per/IV/2008, Port Health Office in airport has the task of carrying out prevention of entry and exit of diseases, potential disease outbreaks, epidemiological surveillance, quarantine, control of environmental health impacts, health services, supervision and security of new diseases and re-emerging diseases, bioterrorism, biological elements, chemicals and radiation security in airport areas. ${ }^{10}$ Port Health Office was implemented by the International Health Regulation (IHR-2005) for prevention occurrence Public Health of International Concern (PHEIC) in Point of Entry. Port Health Office has capacity to reduce public health impacts, especially the spread of infectious diseases. It has carried out vector control guidance, supervised sanitation of transport equipment, improved clean and healthy living behavior and general health and improved occupational safety and health. Many biological agents that cause potential outbreaks come from outside of Indonesia with newly emerging, reemerging/resurging and delicately emerging species, so that to reach Indonesia they require a series of trips that are quite far like SARS from China, MERS CoV, from the Middle East, Avian Influenza from China, HIV from Africa etc. ${ }^{11}$ Based on these incidents, it can be said that airports act as one of the entry points for spread of diseases in Indonesia that are spread by passengers and goods contaminated with dangerous biological materials, or deliberately distributed by certain groups to cause fear or threaten state security. The spread of diseases in a country can occur not only from its own agents but also there are several factors that influence it, namely bad sanitation, bad nutrition, presence of diseases, irrational use antibiotic, antibotic uncontrolled distribution, uncovered vaccination and rejected vaccination, bad environmental situations, dis- eases coming from wildlife, terrorism, fast moving personnel from the area to another area, lack of biosafety in livestock. ${ }^{12}$ Main important properties for biological agent intentional deliberate are route of entry, environmental stability, disease severity, stability against disinfection, ease of large scale production and infectivity. ${ }^{12}$

\section{Biocrime}

The spread of biological agents in airports that occurs deliberately for the purpose of criminal acts by using a biological agent known as Biocrime. Biocrimes is activating by using biological agents, for murder, for profit, distribution of fake vaccines or antibiotics. Some biocrime activities are attacks on specific ethnic population groups within a country, who are perceived to be opposition to terrorist goals; sabotage of specific food groups, such as contamination of imported food products with toxins, pathogenic bacteria, or poison and attacks directed at one of the country's institutions, agencies, or military departments, a stock market, or a major communications center. ${ }^{13}$ Biocrime actions carried out through airports that have occurred have been delivery of antibiotics or substandard vaccines for advantages.

\section{Bioterrorism}

Bioterrorism is intentional use of microorganism or toxin derived from living organism to cause death or disease in humans or the animal and plans. ${ }^{13,14,18,19}$ Bioterorrism might include such deliberate

Table 1. Arrivals of aircraft, passengers, cargo and baggage of domestic flight, 2013-2017. ${ }^{8}$

\begin{tabular}{lcccc} 
Year & Aircraft (units) & $\begin{array}{c}\text { Arrivals of domestic flight } \\
\text { Passenger (person) }\end{array}$ & Baggiga (ton) \\
2013 & 800,193 & 77.568 .403 & 469,149 & 613,197 \\
2014 & 769,762 & $73,889,533$ & 392,566 & 565,883 \\
\hline 2015 & 791,783 & $75,593,248$ & 496,300 & 568,726 \\
2016 & 894,104 & $87,208,889$ & 445,445 & 735,193 \\
\hline 2017 & 972,863 & $95,401,545$ & 557,653 & 729.283 \\
\hline
\end{tabular}

Source: Air Transportation Statistic 2017.

Table 2. Arrivals of aircraft, passengers, cargo and baggage of international flight, 2013-2017.8

\begin{tabular}{lcccc} 
Year & Aircraft (units) & $\begin{array}{c}\text { Arrivals of domestic flight } \\
\text { Passenger (person) }\end{array}$ & Cargo (ton) & Baggage (ton) \\
2013 & 89,478 & $13,136,131$ & 190,952 & 172,484 \\
2014 & 107,353 & $13,245,568$ & 182,545 & 173,287 \\
\hline 2015 & 95,623 & $13,175,804$ & 185,426 & 168,707 \\
2016 & 99,189 & $14,462,373$ & 188,804 & 177,273 \\
\hline 2017 & 110,084 & $16,253,259$ & 223,901 & 208,485 \\
\hline
\end{tabular}

Source: Air Transportation Statistic 2017. 
acts as Salad contamination with Salmonella, injection of HIV virus, anthrax spread by mail, spreading a virulent disease among animal production facilities, poisoning water, food and blood supplies. ${ }^{14}$ Use biological agents for threats is becoming increasingly possible for terrorist groups. Developing microorganism with increasing lethality for terrorist attacks and the rise of religious terrorism call for political, theological, tactical and strategic disincentive to using as weapons and perpetrating acts of mass destruction. Beside that perception use of weapons undermine their political support; motivation religious terrorist for increase threat of mass destruction. ${ }^{14,17-19}$ Until now, acts of terrorism through airports in Indonesia have never happened, but in the future airport can be target of acts of terrorism cause airport is place, when many people from domestic or international gather together for travel. If terrorism attacks happen it will impact reducing international credibility and influence economy, politics, and security conditions.

\section{Biowarfare}

During war use of biological agents is known as biowarfare, which is an action using microorganisms (bacteria, viruses) or toxins found in weapons for war, with the intention of reducing abilities, causing illness, and killing. ${ }^{15-19}$ Open biological warfare until now has never happened, it is estimated that air transportation is the most effective means for biological warfare. Using biological agent intentionally as weapons has advantages: they often are low cost of producing many biological agent, small quantities may have dramatic effects, deadly or incapacitating effect on a susceptible, they are easily disseminated, difficulty in diagnosing index cases, can result in fear, panic and social disruption and symptoms can mimic endemic, naturally occurring disease. ${ }^{14-19}$

Some of key factors for pathogenic biological agents being deliberately distributed rise from several considerations: availability of production in sufficient quantity, ability to cause either lethal or incapacitating effects are achievable and deliverable, appropriate particle size in aerosol, ease of dissemination, stability (while maintaining virulence) after production in storage, weapons and environment, victims of nonconsensual performance of friendly forces ${ }^{17}$ Countermeasures of spread biological agent are based on characteristic of pathogenicity of the organism, mode of transmission and host range, availability of effective preventive measures and availability of effective treatment. ${ }^{17}$ According on Global Health Security countermeasure bio- logical agent spread are prevent, detect, respond and IHR related hazards and point of entry. Where prevent and reducing the likelihood of outbreak and other public health hazards and event defined by IHR is essential, detecting the threat early can save lives, while rapid and effective response requires multisectoral, national and international coordination and communication, IHR capacities are required at points of entry and during chemical events and radiation emergencies. ${ }^{20}$

\section{Indonesia Airport to prevent bio- logical threat}

Indonesia has law to regulate the impact of advances in transportation technology and the era of free trade that could risk causing health problems and new emerging diseases or re-emerging diseases that reappear with faster spread and the potential to cause Public Health emergency. ${ }^{21}$ At present momenti, prevention of infectious diseases in the airport is carried out by the Ministry of Agriculture or by the Quarantine Service, passengers who experience illness suspected of contracting an infectious disease are carried out by the Port Health Office, but not all airports have Quarantine Officers and Port Health Offices. At present based on data from the Ministry of Health, the International Port Health Office amounts to 27 International Airports, so still many airport aren't have Port Health Office. ${ }^{8}$

The current condition between health airport and aviation medicine at the TNI base is not well established, so that if there is a threat of disease outbreaks coming through the airport and at the airport there is no Port Health Office, there will be a delay in the initial handling of victims. In this regard, role of aviation health, both doctors qualified as flight surgeons and flight nurses in air force bases need to be empowered, so that there is no spread of infectious diseases in the environment.

\section{Aviation Medicine Capacity}

Aviation medicine have authority to examine, determine diagnoses, and evaluate the results of pilots' health checks, where the legal product is in the form of aviation health certificate. ${ }^{22}$ Part of the duties and functions of Aviation medicine in air force is providing health support and health services in flight. Flights surgeons at air bases have role of carrying out preventive, curative activities on flight crews the role of aviation health in airports in an effort to prevent spread of infectious diseases originating from passengers and goods is to take preventive actions by conducting detection and identification, handling victims and carrying out referral actions. ${ }^{4}$ Besides that, it cooperates with the occupational health and safety department and conducts checks and prevention. The collective effort is aimed at improving defenses against biological attacks. ${ }^{23}$ Within these efforts are programs and agencies working towards increasing data collection, analysis, and intelligence gathering. The intelligence is applied to mitigating the effects of bioweapons by developing vaccines, therapeutics, and detection methods to increase the defensive posture, ultimately, biodefense initiatives protect the military forces and citizens from the effects of biological attacks. ${ }^{23}$

Some steps that must be considered in increasing capacity of aviation medicine in air force, such as institutionalize \& build regional and sub-regional mechanisms. The ramp up implementation of international frameworks make timely and relevant policies shifts to the address of disease risk drivers, regular capacity building initiatives with focus on preventing, strengthen surveillance and response, laboratory strengthening and networking, strength risk communication, invest in public health research, and map success stories from the region. ${ }^{23}$ Aviation medicine in air force is expected to have ability in preventive activities, detection and identification and handling of victims of infectious diseases in the context of overcoming the spread of infectious diseases at airports.

Preventive Epidemics include natural outbreaks and intentional outbrakes or leakage accidents (releases). Types of preventive measures include (1) Preventing emergence and spread of antimicrobial drug resistant and emerging zoonotic diseases and governing international regulatory frameworks for food safety. (2) Promoting national biosafety and biosecurity systems and (3) Reducing number and magnitude of infectious disease outbreaks. ${ }^{20}$ The strategy for prevention of biological incidents includes strength of biological and toxin weapons convention, control of dual use equipment, improve control of pathogens and genetic material, improve international cooperation, improve scientific research and improve backups, check experts working in class $3 / 4$ labs. ${ }^{23}$

Detection and identification activities carried out by laboratory, military institutions, $\mathrm{MoH}$ by implementing detect threat early. Conduct early detection of threats which include: (1) Launching, strengthening and linking global networks for realtime biosurveillance (2) Strengthening global norm of rapid, transparent reporting and sample sharing in the event of health 
emergencies of international concern (3) Developing and deploying novel diagnostics and strengthening laboratory systems (4) Training and deploying workforce effectively for biosurveillance. ${ }^{20,24}$

Response activities were carried out by military hospitals, public hospitals, hospital $\mathrm{MoH}$ which included decontamination of personnel, equipment (thermos scanner), facilities and infrastructure, health care for victims, responding rapidly and effectively in dealing with biological threats as international attention. (1) Developing an interconnected global network of emergency operations centers and multisectoral responses to biological incidents. Encourage the strengthening of emergency operations centers: multisector emergency response teams that are trained, know how to function, have access to real time information systems and capacity to strengthen information on occurrence of outbreaks. (2) Improving global access to medical and non-medical countermeasures during health emergencies. $^{20}$

\section{Enhancing capacity on facing bio- logical threat}

Enhancing capacity of aviation medicine in the face of the threat of the spread of dangerous biological agents is by measures on prevention, detection, and response can be done by increasing capacity of personnel and equipment. Enhance capacity building (1) Personnel by carrying out procurement, force structure and unit design, (2) Equipment by making systems and equipment (thermos scanner, decontamination), facilities. (3) Readiness by implementing training education, training Table Top Exercise (TTX), Field Top Exercise (FTX) simulation, socialization of code of conduct and operational, equipment maintenance, supply stocks. Interoperability beside stage holder national, regional and international to detect and respond biological threat on laboratory collaborating center, quarantine and observation personnel, treatment of the victim. Some capacity-building activities that must be increased in stages and are sustainably are training to improve military medicine capacity in dealing with infectious diseases carried out by the Ministry of Defense and the TNI, Ministry of Health, and Ministry of Agriculture, Ministry of Transportation, Ministry of Law and Human Right in form exercise are TTX and FTX activities nationally. Training in order to increase the ability to overcome infectious disease outbreaks at the ASEAN level and International. The prevailing WHO recommendations for the contact tracing of air travelers should be modified to include all possible sources of infection. The WHO should intensify its existing successful collaboration with organizations such as ICAO, IATA, and ACI in order to promote procedures for the effective management of highly contagious and life-threatening diseases. $^{9}$

\section{Conclusions}

Airports need high security procedures, especially preventing outbreaks of infectious diseases spread by passenger and carried goods. Outbreaks of diseases form real threat to national defense that can endanger national sovereignty, territorial integrity and national security. Biological agents are dangerous sources of outbreaks infectious diseases that can be spread by criminal and terrorists with biological warfare intentions.

Aviation medicine has a strategic role in preventing, mitigating and rehabilitating the threat of dangerous biological agents. Increasing role of field health under the Air Force Medicine has an important role in overcoming the threat of hazardous biological agents, role of the hospital as a support to victims in the field, and the role of the air force pharmaceutical institutions in the identification of biological agents. Interoperability is needed between Air Force Medicine, Port Health Office, Quarantine Office, Immigration, Authority Airport to prevent, detect and respond outbreak of disease in Airport.

Increased flight health capacity in the face of threat of spread of biological agents by increasing the number of personnel who have the ability with multilevel and continuous training, fulfillment of facilities and infrastructure which include means of decontamination, prevention, detection and identification and handling of victims, training and operational, equipment maintenance, stock operating costs.

\section{References}

1. Kementerian Pertahanan Republik Indonesia.Peraturan Menteri Pertahanan RI Nomor 23Tahun 2015 tentang Buku Putih Pertahanan Indonesia; 2015.

2. SEAL of The President of the United State of America. National Biodefense Strategy; 2018.

3. Undang-Undang RI Nomor 24 Tahun 2007 tentang Penanggulangan Bencana; 2007.

4. Kementerian Kesehatan Republik Indonesia. Peraturan Menteri Kesehatan RI Nomor:44 Tahun 2014 tentang
Penyelenggaraan Pelabuhan dan Bandar Udara Sehat.

5. Badan Pusat Statistik-Statistic Indonesia. Statistical Yearbook of Indonesia 2018. CV. Dharmaputra; 2018.

6. Kementerian Kesehatan Republik Indonesia. Profil Kesehatan Indonesia Tahun 2017, Kementerian Kesehatan RI; 2018.

7. Badan Pusat Statistik Indonesia. Air Transportation Statistics; 2017.

8. Kementerian Kesehatan RI. Laporan Kegiatan Kantor Kesehatan Pelabuhan Indonesia Tahun 2015 pada Pertemuan Audiensi Menteri Kesehatan dengan Kepala KKP seluruh Indonesia; 2016.

9. Walter G, Goetsch U, Diel R, et al. Screening for Infectious Disease at International Airport : The Frankfurt Model. Aviat Space and Environ Med 2009; 80:595-600.

10. Kementerian Kesehatan RI. Peraturan Menteri Kesehatan Nomor: 356/Menkes/Per/IV/2008 tentang Organisasi dan Tata Keja Kantor Kesehatan Pelabuhan; 2008.

11. Antony S. Fauci, Responding to Infectious Disease Outbreaks. NIH, NIAID 2017;14.

12. Andre R, Birgit H, Bernd N, Frank S. CBRN Protection: Managing of Threat of Chemical, Biological, Radiological and Nuclear Weapons. 1st ed. Weinheim: Wiley-VCH Verlag\& Co; 2013.

13. Ryan JR. Biosecurity and Bioterrorism: Containing and Preventing Bilogical Threats. 2nd ed.ButterworthHeinemann: Elsevier Inc.; 2016

14. Benjamin C. The Changing Face of Terorrism: How Real is the Threat from Biological, Chemical and Nuclear Weapons? New York: I.B. Tauris \& Co. Ltd.; 2011.

15. Kristy YJ, Paul MN. Biological Weapons: Recognizing, Understanding and Responding to the Threat. New York: John Wiley \& Sons; 2016

16. Aan LM. Biological, Chemical, and Radiological Terrorism, Emergency Preparedness and Response for the Primary care Physician. Oregon: Springer; 2008.

17. Jeffrey L, Segal LM, Alpert LD, Laurent R.Outbreaks: Protecting Americans From Infectious Disease. Robert Wood Johnson Foundation; 2014.

18. Jansen HJ, Breeveld FJ, Stijnis C,Grobusch MP. Biological Warfare, Bioterrorism, and Biocrime.Clin Microbiol Infect 2014;20:488-96 .

19. Mahendra P,Tsegaye M, Girzaw 
F, et al. An Overview on Biological Weapons and Bioterorrism. Am J Biomed Res 2017;5:24-34.

20. World Health Organization. Joint External Evaluation tool: International Health Regulation; 2005.

21. Undang Undang RI Nomor 6 Tahun 2018 tentang Kekarantinaan Kesehatan; 2018.
22. Dominiques RM, Endang W, Johnny W.Peran Dokter Penerbangan dalam Pelaksanaan Kewajiban Pemeriksaan Kesehatan bagi Penerbang untuk Keselamatan Penerbangan, Soepra, Jurnal Hukum Kesehatan 2017;3.

23. Homeland Defense Business Unit Edgewood Chemical Biological Center U.S Army Research. Development and
Engineering Command, Biological Incident Operation: A Guide for Law Enforcement; 2004.

24. Reynolds MS, Jennifer G. Laboratory Biorisk Management: Biosafety and Biosecurity.Boca Raton: Taylor\& Francis Group; 2015. 